\title{
Earplug as a Barrier on Hearing Disorders Due to Noise Exposure by Tri Niswati Utami
}

Submission date: 09-May-2020 03:37PM (UTC+0700)

Submission ID: 1320222276

File name: Earplug_as_a_Barrier_on_Hearing_Disorders_revisi.pdf (428.96K)

Word count: 2963

Character count: 14975 


\title{
EARPLUG AS A BARRIER ON HEARING DISORDERS DUE TO NOISE EXPOSURE
}

\author{
Tri Niswati Utami ${ }^{1}$, Rinaldo Winata ${ }^{2}$, Sahrir Sillehu ${ }^{3}$, \\ Rapiah Sarfa Marasabessy ${ }^{4}$, Nuraini $^{5}$ \\ ${ }^{I}$ State Islamic University of North Sumatera Medan, ${ }^{2}$ PT Socfindo Tbk, ${ }^{3}$ Institute of \\ Health Science "Maluku 11 isada", Indonesia, ${ }^{4}$ Darussalam University Ambon, \\ ${ }^{5}$ Health Institute Helvetia Medan, Indonesia
}

\begin{abstract}
The use of production machinery in the industry is getting higher. Noise due to production machinery disturbs workers, resulting in hearing loss for workers. Deafness due to industrial noise is one of the diseases caused by work. The purpose of the study was to analyze noise intensity and analyze the benefits of earplug on hearing loss. This research is a quantitative study, the design used is a cross-sectional study. The population is workers at PT X who are exposed to noise intensity of $81-89 \mathrm{~dB}$ of 77 workers. Total population sampling technique. Data analysis using Spearman correlation (rs). The results of the analysis have no relationship to noise intensity with the right audiometry value (p-value = $0.895)$, there is no correlation between noise intensity and left audiometric measurements $(\mathrm{p}$-value $=0.581)$. Workers use personal protective equipment so that noise intensity does not affect hearing function. Earplugs used when working are useful as barriers to protect hearing, able to reduce noise intensity by $30 \mathrm{~dB}$. There is a relationship between right and left audiometry ( $\mathrm{p}$-value $=0,000$ ). Decreasing the hearing power in the right ear will result in a decrease in hearing the power in the left ear, and vice versa. The auditory structure of the right and left ears has anatomically uninterrupted pathways (interconnected channels). Conclusion Earplugs function effectively to protect the ears from hearing loss, therefore it is highly recommended that you always use earplugs during work.
\end{abstract}

Keywords: Audiometry, Personal protective equipment, Earplug, Hearing loss, Noise intensity.

\section{INTRODUCTION}

The World Health Organization 3NHO) said that in 2013 as many as 360 million people in the world experienced hearing loss, of which 180 million people who experience hearing loss are in the Southeast Asia region ${ }^{(1)}$. Occupational diseases due to noise exposure rank first in the United States and Europe.

Corresponding Author:

Dr. Tri Niswati Utami, M.Kes

Public Health Faculty

State Islamic University of North Sumatera

Medan

Email: triniswatiutami@uinsu.ac.id
Hidayat et al. (2014) found $63 \%$ of employees experienced sensorineural hearing loss, who worked in the production room of PT Alas Kusuma, Kubu Raya Regency. This industry is engaged in wood which produces plywood, block boards, sawn timber and paper overlays, noise intensity of 93.3 $\mathrm{dB}^{(2)}$. The 2018 Regional Health Research notes the causes of hearing loss include: deafne 3 s $0.09 \%$, cervical blockage $18.8 \%$ and $2.4 \%$ secretions in the ear canal ${ }^{(1)}$. Hearing loss causes decreased sensitivity to received sound impulses. Some of the causes that reduce hearing power based on the results of Regional Health Research come from 
human physiology, not from factors outside the environment or work environment.

Indonesia as a developing country has experienced rapid progress in the field of industry with the availability of industrial machinery for the production process and producing company products. The use of industrial machinery creates noise in the work environment. Unwanted sounds that exceed the ear's ability to receive them are called noise. Sources of industrial engine noise can result in hearing loss for workers.

Hearing loss occurs due to several reasons, such as age factor, obstruction of 2he ear canal, secretion in the ear, exposure to noise, long exposure to noise, air pressure and drug use. Industrial noise sources come from production machines. Industries generally use machines that produce noise in the work environment, and this noise is received by workers during their work. The longer workers exposed to the noise the more at risk of experiencing occupational diseases. Aksurali (2010) states that hearing loss is initially temporary, becomes permanent if it is continuously exposed to noise in the workplace which can lead to workplace accidents ${ }^{(3)}$.

Hearing loss due to noise exposure cannot be cured, only can be prevented by noise control efforts ${ }^{(4)}$. One action that can be done is to provide ear protectors or APT (Ear Protector). The use of ear protectors, based on the results of Rahayu's P, research (2016), the company provides pre molded Ear Protector for workers exposed to noise. The tool is able to reduce noise by $25-27$ $\mathrm{dB}$, but workers feel uncomfortable using this type of Ear Protective Equipment, so many workers who do not use Ear Protector Equipment while working, the impact found complaints include: workers feel the ears often buzzing $(52 \%)$, often dizzy (36\%), listening to television with very loud volume $(60 \%)$, pain in one or both ears (14\%) and found $38 \%$ screaming when talking ${ }^{(5)}$.

Research at PT X has noise intensity between 81 - 89 decible. Data obtained in the field found 22 workers experiencing hearing loss. Workers are given a personal protective device (PPE), the earplug, workers use PPE but sometimes release the device when the worker. Departing from this problem, it is necessary to analyze the use of earplugs as ear protectors, so as to provide motivation for workers to adhere to the rules and standards of work procedures and support the company to implement health protection for workers. Research problem: does the noise intensity affect hearing? Are earplugs useful to prevent hearing loss? The aim of the study: to analyze the intensity of noise to decrease hearing and analyze the benefits of earplugs to prevent hearing loss.

\section{MATERIAL AND METHOD}

This research is a quantitative study, the design used is a cross-sectional study. The study was conducted for 6 months, from May 2018 to October 2018. The population of this study was all workers in the PT X production section. The sample was taken by means of the total population, as many as 77 workers in the production section of PT X. Data were collected by directly measuring the noise intensity and worker audiometry examination at PT $\mathrm{X}$ by the company doctor.

Data analysis through several stages, namely: Univariate, data analyzed and presented in the form of a frequency distribution of $e_{5} \mathrm{ch}$ research variable. The next step is to test the normality of the data, this test is done to 5 etermine the next bivariate analysis. If the results of 
data analysis are normally distributed using parametric tests (product moment correlation), and if the data is not normally distributed using nonparametric tests (Spearman correlation). The next stage is bivariate analysis using Spearman Correlation (rs) because the research data scale is ratio and data is not normally distributed (non-parametric test).

\section{RESULTS AND DISCUSSION}

The data obtained from this study are grouped in two parts, namely univariate data consisting of the characteristics of the research respondents based on age, years of service, noise intensity, and hearing loss can be seen in the table below:

Table 1 Characteristics of Age and Working Period

\begin{tabular}{|c|c|c|}
\hline Age (year) & $\begin{array}{c}\text { Frequency } \\
\text { (f) }\end{array}$ & $\begin{array}{c}\text { Percentage } \\
(\%)\end{array}$ \\
\hline $24-33$ & 12 & 15,6 \\
\hline $34-43$ & 56 & 72,7 \\
\hline $44-53$ & 9 & 11,7 \\
\hline Amount & 77 & 100 \\
\hline $\begin{array}{c}\text { Working } \\
\text { Period } \\
\text { (year) } \\
<5\end{array}$ & $\begin{array}{c}\text { Frequency } \\
\text { (f) }\end{array}$ & $\begin{array}{c}\text { Percentage } \\
(\%)\end{array}$ \\
\hline $5-$ & 8 & 10,4 \\
\hline 10 & 7 & 9,1 \\
\hline$>10$ & 62 & 80,5 \\
\hline Amount & 77 & 100 \\
\hline
\end{tabular}

Based on age, the majority of workers aged 34-44 years were 56 people $(72.7 \%), 24-33$ years as many as 12 people $(15.6 \%)$ and aged 44 - 53 years as many as 9 people $(11.7 \%)$. Age is at risk for hearing loss. Decreasing hearing thresholds due to age or presbycusis is the most common cause in developed countries $^{(6)}$. The majority of respondents of productive age hearing function has not decreased, but hearing loss due to noise is very common in the age group $>$ 40 years $^{(7)}$.

Based on years of work, the majority of workers have a tenure of $>10$ years totaling 62 people $(80.5 \%)$, work period $<5$ years 8 people $(10.4 \%)$ and working period of 5 - 10 years 7 people $(9.1 \%)$. Previous research revealed the prevalence ratio (RP) of hearing loss 2.1 $(R P>1)$ indicating that working period is a risk factor for hearing loss ${ }^{(8)}$.

Table 2 Respondents Exposed to Noise Intensity

\begin{tabular}{|c|c|c|}
\hline $\begin{array}{c}\text { Noise } \\
\text { Intensity } \\
(\mathbf{d B})\end{array}$ & $\begin{array}{c}\text { Frequency } \\
\text { (f) }\end{array}$ & $\begin{array}{c}\text { Percentage } \\
(\boldsymbol{\%})\end{array}$ \\
\hline $\begin{array}{c}\text { Normal }(< \\
85)\end{array}$ & 20 & 26,0 \\
\hline $\begin{array}{c}\text { Noisy }(\geq \\
86)\end{array}$ & 57 & 74,0 \\
\hline Amount & 77 & 100 \\
\hline
\end{tabular}

The noise intensity is grouped into 2 normal and noisy categories, workers who work in the production section and are exposed to noise $>86 \mathrm{~dB}$ as many as 57 people $(74 \%)$. Exposure to noise received by workers exceeds the appropriate threshold value. Suma'mur (2009) mentions noise intensity in Indonesia which is used as a guideline for hearing protection so that there is no hearing loss which is 8 hours a day for 5 working days (40 hours a week) is $85 \mathrm{~dB}$ (A). This provision was agreed upon for 3 decades, and finally became a national $\operatorname{standard}^{(9)}$.

Table 3 Hearing Loss experienced by Workers

\begin{tabular}{|c|c|c|}
\hline $\begin{array}{c}\text { Hearing } \\
\text { disorders }\end{array}$ & $\begin{array}{c}\text { Frequency } \\
\text { (f) }\end{array}$ & $\begin{array}{c}\text { Percentage } \\
(\mathbf{\%})\end{array}$ \\
\hline $\begin{array}{c}\text { There is no } \\
\text { interference }\end{array}$ & 55 & 71,4 \\
\hline $\begin{array}{c}\text { Hearing } \\
\text { disorders }\end{array}$ & 22 & 28,6 \\
\hline Amount & 77 & 100 \\
\hline
\end{tabular}


Based on the table above, it was found that hearing loss was experienced by 22 workers $(28.6 \%)$ and workers who did not experience 55 hearing loss 4 $1.4 \%$ ). Hearing loss which looks a very common health issue but affects nearly $10 \%$ of the world population as indicated by many international studies. Hearing disorders effectively frail sensitivity to the sounds ordinarily heard ${ }^{(10)}$. Liang $\mathrm{K}$ et al. (2018) stated that environmental and human activities can be at risk for ear disorders, such as upland residents who carry out daily activities in the lowlands experiencing changes in barotrauma air pressure $^{(11)}$.

\section{Bivariate Analysis}

Audiometric measurement data is numerical and abnormally distributed data, so that data analysis is adjusted to the data obtained using non-parametric tests. The following are the results of analysis of Spearman correlation nonparametric test (rs).

Table 4 Correlation of Noise Intensity with Audiometry Measurements

\begin{tabular}{|l|c|c|c|c|}
\hline \multicolumn{1}{|c|}{ Variable } & Correlation value & $\begin{array}{c}\text { Noise } \\
\text { Intensity }\end{array}$ & $\begin{array}{c}\text { Right } \\
\text { Audiometry }\end{array}$ & $\begin{array}{c}\text { Left } \\
\text { Audiometry }\end{array}$ \\
\hline Noise & Correlation coefficient & 1,000 & 0,015 & $-0,064$ \\
\cline { 2 - 5 } Intensity & Significant $(p$ value) & - & 0,895 & 0,581 \\
\hline Right & Correlation coefficient & 0,015 & 1,000 & $0,647 * *$ \\
\cline { 2 - 5 } Audiometry & Significant $(p$ value) & 0,895 & - & 0,000 \\
\hline $\begin{array}{l}\text { Left } \\
\text { Audiometry }\end{array}$ & Correlation coefficient & $-0,064$ & $0,647 * *$ & 1,000 \\
\cline { 2 - 5 } & Significant $(p$ value) & 0,581 & 0,000 & - \\
\hline
\end{tabular}

The 1esults of the Spearman correlation noise intensity with the right audiometry obtained a value of $\mathrm{r}=0.015$ and the value of $\mathrm{p}=0.895$ showed no relationship between noise intensity and right audiometry. Noise intensity with left audiometry obtained a value of $\mathrm{r}=$ 0.064 and the value of $\mathrm{p}=0.581$ showed no relationship between noise intensity and left audiometry. Increased audiometry results of 22 workers and diagnosed with hearing loss were not caused by noise exposure but were indicated due to other factors not examined such as drug use, cerumen blockage, earwax, lifestyle, smoking behavior and others.

Although workers are exposed to noise but are not related to statistical audiometry glues. The results of monitoring workers use Personal Protective Equipment so that noise does not interfere with hearing power. Ear plugs that are used when working are useful for protecting hearing function. Research by Fredinanta et al. (2013) describes the efforts to reduce noise can be done by controlling at the recipient level. The use of ear plugs provides benefits as ear protectors against the decreased hearing. This tool can reduce noise by $+30 \mathrm{dBA}$ so that the earplug effectively protects the ear from noise exposure $^{(12)}$.

Workers exposed to noise levels 80 - $85 \mathrm{~dB}$ are not required to use Personal Protective Equipment, based on Minister of Manpower Decree No. 13 of 2011, because noise sources are at the noise threshold for 8 working hours per day. Workers are advised to use Personal Protective Equipment in this zone, to prevent Occupational Diseases. Measurement of noise intensity at PT X 
found 12 points above the threshold value $(85-90 \mathrm{~dB})$ zones must use Personal Protective Equipment ${ }^{(13)}$.

The measurement of right and left audiometry values obtained $r=0.617$ and the value of $p=0,000$ means that there is a relationship between the right audiometry and left audiometry and shows a strong and positive pattern, meaning that the higher the right audiometric value the ${ }_{1}$ higher the left audiometric value. Decreasing the hearing power in the right ear will result in a decrease in hearing the power in the left ear, and vice versa. Research conducted to prove the ability to hear between the right and left ears, the test involved 41 people aged 19-28 years. Samples are given different information through headphones. The test results found no difference between the functions of the right and left ears in capturing information ${ }^{(14)}$.

Based on the audiogram measurement standard, the classification of deafness is based on audiogram values as follows:

Table 5 Classification of Results of Measurement of Worker Audiometry and Deaf Classification

\begin{tabular}{|c|c|c|}
\hline Category & $\begin{array}{c}\text { Audiometry Value } \\
\text { Standard (dB) }\end{array}$ & $\begin{array}{c}\text { Audiometry Value } \\
\text { Standard (Person) } \\
\text { Measurement Results }\end{array}$ \\
\hline Normal & $0-25$ & 55 \\
\hline Mild deafness & $26-40$ & 21 \\
\hline Being Deaf & $41-60$ & 1 \\
\hline Deafness is heavy & $61-90$ & 0 \\
\hline Very heavy Amount & 77 \\
\hline \multicolumn{2}{|l}{} \\
\hline
\end{tabular}

High audiometry value means hearing loss, and the results of analysis based on Spearman test found that the relationship between right ear hearing loss will have an impact on hearing the loss in the left ear. The hearing loss is usually slow in onset but progresses relentlessly for as along as the exposure continues. Indeed, the harmful effects may continue long after noise exposure has ceased. They are irreversible ${ }^{(15)}$. In accordance with the results of the study, the ability to hear the right ear is related to the ability to hear the left ear, the auditory structure of the right and left ears anatomically has an unbroken relationship path (interconnected channels). Sound received by someone, in the form of vibration in the eardrum. Vibration is produced from a number of variations in air pressure produced by the sound source and propagated by the surrounding medium, called the acoustic field. This sound changes from an acoustic signal to an electrical signal and is transmitted by the auditory nerve to the brain $^{(16)}$. Sound localization requires the cooperation of both ears. A sound source close to the right ear will enter the brain earlier than the left ear, but if the sound source is in a straight position it will reach both ears at the same time. 


\section{CONCLUSIONS AND RECOMMENDATIONS}

1. The earplug functions to effectively protect the ear from hearing loss, therefore it is very good to still use earplug during work.

2. The decrease in the hearing of the right ear is associated with a decrease in hearing the power in the left ear because the ability to hear the right ear is related to the ability to hear the lift ear.

3. There is no correlation between noise intensity and hearing loss, although the intensity of noise in the workplace exceeds the threshold value does not affect the hearing of workers because the earplug can reduce noise intensity $\pm 30 \mathrm{~dB}(\mathrm{~A})$.

\section{ACKNOWLEDGMENTS}

Directors, managers and all employees of PT X for the support and permission of the research provided, and willingness to become research respondents.

\section{Conflict of Interest ： Nil}

Source of Funding : Self

Ethical Clearance : Cleared

\section{REFERENCES}

1. Ministry of Health of the Republic of Indonesia. Healthy Ears Investing in the Future. Jakarta: Friday, March 2, 2018. Retrieved from www.depkes.go.id. p 1 -3.

2. Hidayat. Effect of Machine Noise Exposure Against Sensorineural Hearing Disorders in Workers in the Production Section of PT Alas Kusuma in Kuburaya Regency in 2013. Pontianak; 2014.

3. Aksurali W. Study of The Causes of Hearing The Loss in Production
Section Workers at PT Sermani Steel Makassar; 2010. p. 1-64.

4. Kandou LFM. Relationship of The Characteristics and Improvement of Flight Hearing in The Health Center. Indones $\mathrm{J}$ Occup Saf Heal. 2013;3(1):1-9.

5. Rahayu P, Pawenang ET. Factors Related to Hearing Disorders in Workers that are Exposed to Noise in Spinning I Units PT. Sinar Pantja Djaja Semarang. Unnes J Public Heal [Internet]. 2016;5(2):140-8. Available from: http://journal.unnes.ac.id/sju/index.p $\mathrm{kp} / \mathrm{ujph}$

6. Jumali; Sumadi; Andriani S, Subhi M, Suprijanto D, Handayani WD, Chodir AN, Fadilatus SI, et al. Prevalence and Risk Factors of Deaf Due to Noise on Ferry Engine Operators. J Kesehat Masy Nas. 2013;7(12):545-50.

7. Dewanty RAS. Analysis of the Impact of Noise Intensity on Hearing Loss Laundry Officers. J Kesehat Lingkung. 2015;8(2):229-37.

8. Ibrahim H, ; Basri S, Hamzah Z. Factors Related to Complaints of Disorders in Labor Production Parts PT. Japfa Comfeed. Al Sihah; Public Heal Sci J. 2016;8(2):121-34.

9. Suma'mur P. Corporate Hygiene and Occupational Health (HIPERKES). Jakarta: CV Sagung Seto; 2009. 116$132 \mathrm{p}$.

10. Chaitanya MTSNKA. A Thorough Invesigation on Designs of Digital Hearing Aid. Indian J Public Heal Res Dev. 2018;9(11):2076-80.

11. Liang, Kevin; Mona, Moudi; Tumbel RE. Community Ear Health Survey in Tinoor Village 2. J e-clinic (e CI). 2018;6(1):27-30.

12. G. Dedy Fredinanta; Huda LNGE. Noise Level Analysis to Reduce 
Noise Exposere Dosage in PT XYZ. J Tek Ind FT USU. 2013;2(1):1-8.

13. Bachtiar, Vera Surtia; Dewilda, Yommi; Wemas BV. Noise Level Analysis and Control Efforts on Production Units in An Industry in Batam City. J Tek Lingkugan Univ Andalas. 2013;10(2):85-93.

14. Putri GS. Right Ear or Left Ear, Which Is Better at Hearing Kompas. Jakarta:
Kompas.com.09/12/2017. 08.31 wib; 2017. p. 1-3.

15. WHO WH. Hearing Loss, Due to Recreational Exposure to Loud Sounds. Genewa: WHO Press; 2015. p. 1-31.

16. Irawati L. Medical Physics of The Hearing Process. Andalas Medical Magazine. 2012;36(2):155-62. 
Earplug as a Barrier on Hearing Disorders Due to Noise Exposure

ORIGINALITY REPORT

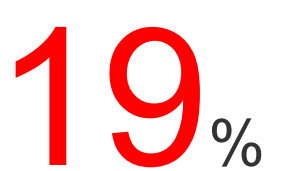

SIMILARITY INDEX
$16 \%$

INTERNET SOURCES
$1 \%$

PUBLICATIONS
$5 \%$

STUDENT PAPERS

PRIMARY SOURCES

1 www.i-scholar.in

Internet Source

$15 \%$

2 Submitted to Wright State University

Student Paper

3 Submitted to Universitas Airlangga

Student Paper

4 vohom.com

Internet Source

$5 \quad$ Submitted to Universiti Teknologi Malaysia

Student Paper 